\title{
ASSASSINATO POR SENTIMENTO DE CULPA: UMA (RE) LEITURA DO CASO CARLOS IN "O CRIMINOSO E SEUS JUÍZES: A PARTIR DE UM PONTO DE VISTA PSICANALÍTICO"
}

\section{MURDER BECAUSE OF GUILT: A RE-READING OF THE CARLOS CASE IN "THE CRIMINAL AND HIS JUDGES: FROM A PSYCHOANALYTIC POINT OF VIEW"}

\author{
Renata Batista Ribeiro \\ Graduada em Psicologia ALFA UNIPAC TO - Brasil. \\ E-mail: renatabr1997@gmail.com \\ Alcilene Lopes De Amorim Andrade \\ Psicóloga, Pós-graduada em Psicologia Clínica, Mestra em Educação, \\ Professora da ALFA UNIPAC TO - Brasil. \\ E-mail: alcileneaguia@hotmail.com
}

Recebido: 17/01/2021 - Aceito: 17/01/2021

\section{Resumo}

Este estudo ocupa-se de assassinatos cometidos por sujeitos de estrutura neurótica, pouco abordado e de menor interesse criminológico e midiático. Freud se dedicou ao estudo daqueles que vivem sob influência de mecanismos psíquicos inconscientes e que mediante esse fato, podem agir de maneira indiscriminada e coativa. Define-se como objetivo do trabalho, discutir, num viés psicanalítico, os aspectos psicológicos envolvidos no assassinato por sentimento de culpa no "Caso Carlos". A metodologia adotada foi pesquisa bibliográfica realizando um estudo de caso, via literatura, do "Caso Carlos in O Criminoso e Seus Juízes: a partir de Um ponto de vista psicanalítico". A literatura revela que, Freud, descrevendo sobre os criminosos em consequência de um sentimento de culpa, referindo-se a diferentes tipos de práticas criminosas, afirmou que as más ações praticadas por esses indivíduos são principalmente em decorrência das penalidades advindas do ato, assim Ihes proporcionando um alívio mental. Uma vez que, o indivíduo sofre por um opressivo sentimento de culpa anterior ao ato, do qual só obtém atenuação após a prática e sua punição. Destaca-se que, o delito cometido pelo neurótico carrega consigo o peso da culpa que é vivenciada. Destarte, encontra-se a partir da psicologia da neurose, um sujeito regido pelo Princípio de Talião, dominante na justiça primitiva, hipermoral e de consciência hipersensível, embora, conjuntamente, seu inconsciente carregue consigo tendências criminosas arcaicas não superadas. Entende-se que, este 
assassinato seria resultante do crime ancestral vivenciado pelo sujeito e sua constituição subjetiva.

Palavras-chave: Psicanálise; Neurose; Culpa, Crime; Autopunição.

\begin{abstract}
This study deals with murders committed by subjects of neurotic structure, little addressed and of lesser criminal and media interest. Freud devoted himself to the study of those who live under the influence of unconscious psychic mechanisms and who through this fact can act indiscriminately and coactively. It is defined as the objective of the work, to discuss, in a psychoanalytic bias, the psychological aspects involved in the murder because of guilt in the "Carlos Case." The methodology adopted was bibliographic research carrying out a case study, via literature, of "Case Carlos in The Criminal and His Judges: From a psychoanalytic point of view." The literature reveals that, Freud, describing about criminals as a result of a feeling of guilt, referring to different types of criminal practices, said that the bad actions practiced by these individuals are mainly due to the penalties resulting from the act, thus providing them with a mental relief. Since, the individual suffers from an oppressive feeling of guilt prior to the act, from which he gets mitigation only after the practice and his punishment. It is noted that the crime committed by the neurotic carries with it the weight of the guilt that is experienced. Thus, it is found from the psychology of neurosis, a subject governed by the Talion Principle, dominant in primitive justice, hypermoral and hypersensitive consciousness, although, together, its unconscious carries with it archaic criminal tendencies not overcome. It is understood that this murder would result from the ancestral crime experienced by the subject and his subjective constitution.
\end{abstract}

Keywords: Psychoanalysis; Neurosis; Fault, Crime; Autopunishment.

\title{
1. Introdução
}

$\mathrm{Na}$ atualidade, são frequentes as pesquisas e discussões acerca dos crimes e assassinatos cometidos por indivíduos de estrutura perversa e psicótica, porém, o que ainda é pouco abordado e tem despertado menor interesse criminológico e midiático, são os assassinatos cometidos por sujeitos de estrutura neurótica. Mas já em 1916, Sigmund Freud em seu trabalho denominado Alguns tipos de caráter encontrados no trabalho psicanalítico, se dedicou ao estudo de pessoas que vivem sob influência de certos mecanismos psíquicos inconscientes e que mediante esse fato, podem agir de maneira indiscriminada e coativa. 
Em seu trabalho analítico, Freud descreve brevemente sobre os criminosos em consequência de um sentimento de culpa, referindo-se à diferentes tipos de práticas criminosas, afirmou que as más ações praticadas por esses indivíduos são principalmente em decorrência das penalidades advindas do ato, assim Ihes proporcionando um alívio mental. Uma vez que, o indivíduo sofre por um opressivo sentimento de culpa anterior ao ato, do qual só obtém atenuação após a prática e sua punição (FREUD, 1916). No entanto, este trabalho irá delimitar seus estudos abordando especificamente o assassinato por sentimento de culpa, tendo seu embasamento na teórica psicanalítica, fundada pelo médico neurologista e estudioso da psique humana aqui supracitado.

Importante ressaltar que, o delito cometido pelo neurótico carrega consigo o peso da culpa que é vivenciada por ele. Destarte, encontra-se a partir da psicologia da neurose um sujeito regido pelo Princípio de Talião, dominante na justiça primitiva, hipermoral e de consciência hipersensível, embora, conjuntamente, seu inconsciente carregue consigo tendências criminosas arcaicas não superadas (ALEXANDER; STAUB, 1927).

Em vista disso, levantam-se questionamentos quanto ao que coopera para tal conduta criminosa, ao ponto de um indivíduo tirar a vida de outro e obter desopressão de seus sentimentos de angústia e culpabilidade inconscientes. Afinal, o que pode estar envolto na origem desse terrível sentimento de culpa, anterior ao ato, que assola esse sujeito? Por que essa satisfação advinda de seu próprio sofrimento e auto castigo após o ato? A partir dessas indagações, surge a pergunta-problema que norteará a pesquisa: Quais aspectos psicológicos envolvidos no assassinato por sentimento de culpa, numa perspectiva psicanalítica?

Frente a indagação levantada como questão central para este trabalho, define-se como objetivo principal, apontar num viés psicanalítico, os aspectos psicológicos envolvidos no assassinato por sentimento de culpa no "Caso Carlos". Especificamente pretende-se: abordar o processo de constituição subjetiva; apresentar o processo de formação da estrutura neurótica e suas especificidades; discutir a relação entre crime, passagem ao ato e autopunição.

Identificar os aspectos psicológicos envolvidos no assassinato por sentimento de culpa, mostra-se de suma importância para o meio científico, 
possuindo relevância acadêmica e social, pois poderá contribuir para que profissionais da saúde, como psicólogos e médicos, possam melhor compreender o sujeito que é acometido por essa enorme afecção mental e tracem uma terapêutica profícua, com prognósticos positivos; assim como, também poderão beneficiar-se os profissionais da área jurídica e criminal ao lidarem com esse tipo de caso e mais adequadamente poderem investigar, avaliar e julgá-lo.

Apresenta-se nesta seção, a organização de conceitos e estudos presentes na literatura psicanalítica, concernente a temática. Os estudos acerca da formação e particularidades da estrutura neurótica, bem como, o sentimento de culpa e a passagem ao ato, constituem o plano de fundo deste trabalho, servindo-se da vasta contribuição das obras freudianas. Contudo, não serão deixados de lado conceitos desenvolvidos por outros estudiosos, que se mostrem de extremo valor para que este estudo obtenha êxito em sua proposta.

\section{Revisão da Literatura}

\subsection{Processo de constituição subjetiva}

Visando a inteligibilidade de alguns aspectos psicológicos que podem estar envoltos no fenômeno do assassinato motivado por sentimento de culpa, faz-se necessário abordar alguns processos psíquicos incomensuravelmente importantes para a compreensão do sujeito que comete tal crime.

Verifica-se a presença de longas discussões na vasta obra psicanalítica quanto ao conceito de sujeito, apontando-o como um carácter peculiar e complexo, haja vista, a abundância de variáveis que interferem direta e indiretamente no processo de constituição subjetiva do indivíduo. Em face das enormes contribuições, pode-se afirmar que o sujeito caracteriza-se de forma única.

Segundo Magalhães e Feres-Carneiro (2005), os estudos freudianos apontam que para além de uma estruturação psíquica somente individual, há uma natureza supraindividual, ou seja, uma intersubjetividade constitutiva, que diz respeito à relação entre os sujeitos. 
Posto isso, pode-se constatar a grande influência familiar para o processo de subjetivação, sendo que, com esse núcleo o infante tem seu primeiro contato ao nascere ao longo de sua vida absorve incalculáveis conteúdos experienciados nesse meio. Em razão disso, Passos e Polak (2004), com base na teoria psicanalítica, aludem a existência incontestável de um psiquismo familiar, composto por conteúdos intrapsíquicos advindos de membros individuais do grupo, tendo como função principal, o partilhamento inconsciente desses conteúdos entre seus membros, a partir de uma organização do funcionamento intersubjetivo. Assim, Magalhães e Feres-Cerneiro (2005), apontam a transmissão psíquica geracional como um fator de extrema relevância para o estudo do indivíduo enquanto processo constitutivo.

Mas para além da influência familiar, há também o meio social no qual essa pessoa será inserida, por tanto, cabe apontar que:

[...] o sujeito só pode se constituir em um ser que, pertencente à espécie humana, tem a vicissitude obrigatória e não eventual de entrar em uma ordem social a partir da família ou de seus substitutos sociais e jurídicos [...]. Sem isso ele não só não se tornará humano [...] como tampouco se manterá vivo: sem a ordem familiar e social, $O$ ser da espécie humana morrerá (ELIA, 2004, p.39)

Para esse sujeito que é objeto de estudo da Psicanálise, é necessário que - nascente seja abraçado pela organização familiar e social para se constituir enquanto ser humano. É fundamental o atravessamento do Outro, as contribuições do Outro para seu processo de formação. Por isso a necessidade da inscrição do sujeito no campo da linguagem, que é habitado pelo inconsciente e o permitindo estabelecer laços sociais (MAGALHÃES; MARIANI, 2010).

Ou seja, para haver esse indivíduo, é vital que ele seja atravessado pelos significantes desses Outros que participarão de sua vida. Orlandi (2002, 2001), fala sobre um sujeito constituído a partir de dois momentos: primeiro, momento de interpelação do indivíduo em sujeito, o qual produz assujeitamento e resulta na inscrição dele no campo simbólico (campo 
da linguagem), de modo a ser afetado por esse e buscar a expressão de sua subjetividade de forma autônoma, por ainda acreditar ser portador da origem de seu dizer; e o segundo momento, que é o processo de individualização pelo Estado, processo pelo qual o indivíduo passa por uma individua(liza)ção, para ser inserido na ordem social, para assim torna-se um sujeito jurídico que deve cumprir ordens e deveres.

Cabe ainda ressaltar, o processo de identificação, que revela-se como um:

Processo psicológico pelo qual um sujeito assimila um aspecto, uma
propriedade, um atributo do outro e se transforma, total ou
parcialmente, segundo o modelo desse outro. A personalidade
constitui-se e diferencia-se por uma série de
identificações (LAPLANCHE E PONTALIS, 2001, p. 26).

Processo esse que mostra-se de grande importância para o sujeito que está se constituindo, e que conforme Passos e Polak (2004) mediante releitura da obra freudiana Psicologia de grupo e análise do ego (1921), a identificação é para o indivíduo uma das formas mais primitivas de expressão do vínculo afetivo com outra pessoa, aspecto que possui enorme participação na história do Complexo de Édipo, tema esse que será abordado na próxima seção.

Portanto, é possível asseverar que o processo de constituição subjetiva ocorrerá mediante a uma miríade de fatores, os quais exercem total interdependência, configurando-se como um processo altamente dinâmico, dialetizador e nodal para efetivação da inscrição do sujeito no campo do seu próprio desejo e também do Outro.

\subsection{O Complexo de Édipo e a formação da estrutura neurótica}

Entende-se que o "[...] complexo de Édipo, trata-se de um conjunto de ideias que giram em torno dos temas do incesto, do parricídio, do amor e do ódio da criança em relação aos pais" (BARRETTA, 2012, p. 158 e 159). Tema esse que fora descrito por Freud através da tragédia grega do Édipo Rei e que mostra-se de grande importância para pesquisa proposta por esse trabalho.

Para que seja abordada a temática acerca do Complexo de Édipo, cabe aqui resumidamente descrever o enredo da história de Édipo, filho de Jocasta e Laio - rei de Tebas. Após o nascimento de Édipo, seu pai consultou um oráculo, 
o qual the assinalou que seu filho, anos mais tarde lhe assassinaria. Posto isso, a criança deveria ser abandonada no deserto para sua morte, o que fora feito, porém, a criança fora salva. Tempos depois, em consulta a um oráculo, o próprio Édipo fora advertido de seu terrível destino - matar seu pai. No intuito de fugir de sua sina, Édipo afasta-se das terras onde habitava, acreditando ser ali o berço de seu nascimento. No entanto, em meio a sua fuga Édipo assassina seu verdadeiro pai - Laio, durante uma batalha (FREUD, 1900).

Édipo então dirige-se à sua terra natal e toma Jocasta como sua esposa, tornando-se rei de Tebas. Tudo estava na mais perfeita ordem, até que Tebas é acometida por uma peste. Mediante consulta ao oráculo, os tebanos descobriram que o fim da peste só chegaria quando o assassino de Laio fosse expulso da corte. À face do exposto, fora revelado que Édipo era o filho de Laio e havia desposado sua própria mãe. Em virtude disso, Jocasta cometerá suicídio e Édipo buscará punição através da perfuração de seus próprios olhos (FREUD, 1900).

Em vista disso, Laplanche e Pontalis (2001, p. 77), definem o Complexo de Édipo como sendo um:

\begin{abstract}
Conjunto organizado de desejos amorosos e hostis que a criança sente em relação aos pais. Sob a sua forma dita positiva, o complexo apresenta-se como na história de Édipo-Rei: desejo da morte do rival que é a personagem do mesmo sexo e desejo sexual pela personagem do sexo oposto. Sob a sua forma negativa, apresenta-se de modo inverso: amor pelo progenitor do mesmo sexo e ódio ciumento ao progenitor do sexo oposto. [...] Segundo Freud, o apogeu do complexo de Édipo é vivido entre os três e os cinco anos, durante a fase fálica; [...] O complexo de Édipo desempenha papel fundamental na estruturação da personalidade e na orientação do desejo humano.
\end{abstract}

Consoante alhures demonstrado, o Complexo de Édipo é caracterizado por uma relação de ambivalência de sentimentos, uma vez que, segundo Markus (2015), o menino desenvolve uma catexia pela mãe e estabelece uma relação de identificação com o pai - não necessariamente trata-se dos progenitores, mas daqueles que exercem tal função para o sujeito. Essa identificação torna-se posteriormente um desejo de livrar-se dele, devido ao seu desejo incestuoso para com sua mãe. É nesse momento que deve haver a inscrição da criança no campo da Lei, através da castração simbólica realizada 
pela figura paterna. Ou seja, a castração está ligada à Lei que fora instaurada, após o menino perceber a diferença anatômica presente em sua mãe, e então temer a perda de seu falo.

[...] chamado Complexo de Castração, em que está latente o medo perante esta pena rara, que representa o fundamento de todas as limitações sociais dos instintos humanos e, ao mesmo tempo, constitui a causa do importante mecanismo de repressão, condicionador de toda a estrutura do aparelho anímico e da diferenciação entre processos psíquicos conscientes e inconscientes. Fala de crime e o castigo, de sacrifício e contrição, da submissão e do rigor das instâncias anímicas, da tendência a se castigare da necessidade de confessar. (ALEXANDER; STAUB, 1927, p.55)

Como apontado pelos autores, o Complexo de Castração desempenha importante papel também na constituição do sujeito enquanto ser social, que para convívio em sociedade deve reprimir seus instintos ancestrais de impulsividade e desejo, e ainda assim, estar tão inteiramente ligado a lei que lhe foi imposta, que em alguns casos o indivíduo busca punição por suas transgressões.

É possível discorrer sobre o Complexo de Édipo a partir de três tempos, nos quais ele é dividido: o primeiro é caracterizado pela relação mãe-criança, em que a criança acredita ser o falo, sendo imaginariamente o objeto de completude da mãe; no segundo tempo a criança percebe que não é o falo, mas ainda sim deseja possuí-lo - rivalizando com seu pai; no terceiro tempo edipiano o infante acredita que o pai detém ofalo, mas estando a caminho da saída do Édipo, conclui que todos são seres de falta, castrados e que ninguém possui o falo (TOREZAN, 2016).

Por conseguinte, ao abordar a saída do Complexo de Édipo é de suma importância que seja posto em pauta a problemática levantada por Lacan ao discutir a questão da heterossexualidade, visto que, o sujeito deve fazer uma escolha objetal heterossexual, e para sua normativa, é necessário que se chegue a tal situando-se corretamente com relação a função paterna. Ou seja, no caso do menino, deve acontecer a identificação com a função paterna, posto que, no futuro o garoto tenderá a exercer tal função, pois "é fato que, para cada homem, o acesso à posição paterna é uma busca" (LACAN, 1957, p. 209). 
Não perdendo de vista o tema Assassinato Por Sentimento de Culpa, é imperioso ressaltar a instalação da estrutura neurótica, que conforme descrito por Torezan (2016), instala-se no sujeito após a passagem pelos três tempos do Édipo, ponto esse em que a castração já fora estabelecida.

Freud (1924 [1923], p. 88), afirma que "a neurose é o resultado de um conflito entre o ego e o id", em que o ego recusa-se a aceitar um impulso instintual do id, defendendo-se através de seu próprio impulso, utilizando o mecanismo de repressão. Porém, o conteúdo reprimido busca emergir através de uma representação substitutiva, então ocorrendo uma conciliação, formando assim o sintoma. Logo, o ego começa a lutar contra o sintoma, que para ele é uma ameaça, então assim constitui-se um quadro neurótico.

Segundo o fundador da psicanálise, o fator determinante para a neurose seria a predominante influência da realidade, visto que, não só na psicose mas também na neurose, o sujeito, mediante uma realidade desagradável tentará substitui-la por algo que seja desejável a ele (FREUD, 1924 [1923]). Assim, fica claro que há um afrouxamento da realidade na neurose e isso constata-se na forma que o sujeito, em sua constituição subjetiva, lida com a realidade exterior, ou seja, por meio da fantasia (POLETTO, 2019).

Em Conferências introdutórias sobre psicanálise (Parte III), Freud (1916[1917]) declara que as psiconeuroses de defesa ou neuroses de transferência, assim denominadas por ele, englobam as neuroses histéricas, fóbicas e neuroses obsessivas. E essa última revela-se como sendo de grande valia para o desenvolvimento dessa pesquisa, portanto, é de abissal importância que seja reservado um espaço para discorrer sobre essa neurose.

\subsubsection{A neurose obsessiva e o sentimento de culpa}

Em seus estudos inicias, Freud muito atentou-se a neurose histérica, mas a neurose obsessiva também fez parte das bases de estudos psicanalíticas. Freud (1916[1917]), apresenta a neurose obsessiva como não sendo tão comum quanto a histeria, mas ainda assim, tornou-se conhecida. Em seu dicionário psicanalítico que revisa a literatura freudiana, Roudinesco (1998), classifica 
a neurose como a segunda grande doença nervosa dentro da classe das neuroses, sendo a neurose obsessiva originada de um conflito psíquico infantil, visto que, com relação as fases de desenvolvimento psicossexual infantil, o indivíduo neurótico fixou-se na fase anal.

De Almeida (2010, p. 42), cauciona que a estrutura do indivíduo define-se a partir do recalque de um trauma sexual infantil. Nos casos neuróticos, a estrutura se instala devido ao fracasso no recalcamento do trauma, experiência traumática essa, que inicialmente proporcionava prazer ao indivíduo. Imperioso ressaltar que, o neurótico obsessivo, diferentemente do histérico, não tem seus sintomas manifestos essencialmente no corpo. O sujeito "obsessivo sofre de pensamentos." Ou seja, é a consciência do obsessivo que se sobrecarrega, que busca uma ressignificação através das atividades cotidianas, censurando esse conteúdo. Para a formação estrutural do neurótico obsessivo é necessário a presença de prazer no trauma, uma vez que, é a partir desse fato que ele buscará a punição sobre seus desejos (SANTANA; DA SILVA, 2018).

Freud (1916[1917], p. 13) assinala que, que os pensamentos do obsessivo são compostos por impulsos que incomodam o indivíduo e que podem causar-Ihe insatisfação em sua realização. Seus pensamentos podem ter conteúdos insignificantes, mas são frequentemente absurdos, o que costumeiramente proporciona ao paciente uma intensa e cansativa atividade mental. Fato que o leva "a remoer pensamentos e a especular, como se se tratasse dos seus mais importantes problemas vitais." Os impulsos dos quais Freud refere-se, via de regra, possuem conteúdos assustadores e podem levar o indivíduo a cometer crimes.

Por conseguinte, Santana e Silva (2018) apontam o controle como uma característica do obsessivo, pois ainda que ele censure o trauma, deseja inconscientemente revive-lo, mas o Superego impede que isso ocorra, resultando assim num sujeito que controla todas as situações tentando evitar reviver o trauma. 
O que ainda mostra-se imprescindível destacar enquanto sintoma, é o sentimento de culpa vivenciado pelo sujeito neurótico. Rinaldi (2014, p. 2), em análise a obra freudiana, declara que:

\begin{abstract}
No campo da clínica comum, ao identificar a força do sentimento de culpa nas contradições e inibições da neurose obsessiva, na autodepreciação melancólica, na resistência terapêutica negativa, no recurso à conduta criminosa pela necessidade de punição, ele reafirma que tudo tem sua origem na relação ambivalente com o pai. No Complexo de Édipo, assim, estão condensados os dois grandes crimes humanos - o parricídio e o incesto - fonte deste "obscuro sentimento de culpa" da humanidade, onde a ontogênese repete a filogênese. Há, assim, para Freud, uma herança da culpa.
\end{abstract}

Consoante a fala da autora, essa culpa que o sujeito sente é herança do crime ancestral cometido pelo infante, o incesto - desejo amoroso com relação à figura materna - e parricídio - o desejo de morte da figura paterna. É esse mais um dos sentimentos que assolam os pensamentos do neurótico obsessivo. Freud (1923), ratifica dizendo que esse sentimento de culpa descrito, normalmente permanece inconsciente, e até mesmo para o autor, a descoberta de que o aumento dessa culpa pode favorecer que o sujeito cometa crimes, fora uma surpresa. Mas Freud declara ser possível detectar a presença desse sentimento no sujeito; uma culpa pré-existente e não resultante do ato criminoso.

Em vista do exposto, percebe-se o quão rica é a estrutura neurótica e essa sua ramificação - a neurose obsessiva. Sendo o obsessivo constituído de enormes contribuições familiares que realmente imprimem sua marca nesse indivíduo enquanto ser desejante. Indivíduo esse que, pode caracterizar-se de formas inimagináveis, e nem caberia aqui apontar todas essas peculiaridades. Mas se fosse possível assinalar algumas características marcantes, certamente seria sua sobrecarga de pensamentos e impulsos que por vezes são conflitivos, e esse sentimento de culpa avassalador.

\title{
2.30 crime como ato
}

Imperioso ressaltar, a relação entre o ato criminoso do neurótico - nesse caso o assassinato - e sua relação com a passagem ao ato. Visto que, é através 
desse ato que o sujeito obtém a atenuação de seu padecimento mental, a culpa. Sendo as palavras homicídio e assassinato sinônimos, Tendlarz e Garcia (2013), conceituam o termo homicídio, segundo o direito penal, como um dos tipos de delitos previstos nas leis penais; sua significação refere-se ao ato de matar outra pessoa. Segundo os autores, geralmente é dada especial atenção aos crimes cometidos por perversos e psicóticos, mas os neuróticos também podem realizar ações criminosas.

Para que aqui seja estabelecida uma relação entre crime e passagem ao ato, é imprescindível que o conceito desse segundo seja apresentado. 0 conceito de passagem ao ato origina-se da clínica psiquiátrica clássica e inicialmente abarcava as "impulsividades de condutas auto ou heteroagressivas, criminais, violentas ou delinquentes." A posteriori tal conceituação sofre modificações e passa a incluir fenômenos mais abrangentes e variados (TENDLARZ; GARCIA, 2013, p. 12).

Lacan (1962-63) atribui a passagem ao ato o conceito de saída ou despencamento da cena ou como descrito no vocabulário francês, laisser tomber, que significa abandonar algo, ou seja, é a realização de "um corte em relação ao campo do Outro, que é o que determina o sujeito enquanto tal" (LINS; RUDGE, 2012, p. 21).

Conforme Salum (2009), a passagem ao ato e acting-out são respostas da psicose e neurose, que ocorrem quando é inexistente para o indivíduo o apoio simbólico (linguagem) para que seja realizada sua inscrição na castração enquanto falta. É a partir da inscrição do sujeito nesse campo, através da castração, que ele entenderá suas limitações e consequentemente, que não pode realizar plenamente seus desejos. Para conseguir lidar com tal situação, o sujeito recorre às respostas supracitadas. Por meio do acting-out sua resposta é a encenação e a fantasia, como forma de disfarçar a falta. Já na passagem ao ato, o sujeito identifica-se como o objeto, uma vez que, falta o apoio simbólico da linguagem como uma forma de elaborar seu sofrimento.

Para Lins e Rudge (2012), a passagem ao ato é o recurso encontrado pelo sujeito para lidar com a angústia. $\mathrm{O}$ ato cometido pelo indivíduo pode ter seu agravamento na violência atribuída a ele, posto que, é a forma encontrada pelo sujeito para solucionar seus conflitos psíquicos. Por esse fato, esse 
mecanismo costuma ser ruidoso - "como sugere a noção de crimes imotivados" (CALAZANS; BASTOS, 2010, p. 251).

Segundo Lacan (1962-63), a falta sentida pelo sujeito é o que gera a angústia. Sendo essa angústia a responsável por sinalizar o perigo, localizando esse perigo no desejo do Outro, pois é nessa relação inscrita no campo do Outro que o sujeito busca o significante e acaba por se alienar, uma vez que, o significante encontrado no outro não lhe define, não completa sua falta.

Nessa busca frustrada pelo objeto de desejo, surge o objeto a que, segundo Roudinesco (1998, p. 551), foi a forma encontrada por Lacan para nomear o objeto desejado pelo sujeito e "que se furta a ele a ponto de ser não representável, ou de se tornar um "resto" não simbolizável". É mediante a presença do objeto pequeno a que ocorre a passagem ao ato. Visto que, Lacan (1967-68) afirma não existir significante capaz de expressar esse significado almejado pelo sujeito.

Com relação ao ato homicida, a passagem ao ato relaciona-se com a fantasia, à satisfação envolvida no ato e às características das vítimas do crime. No caso do neurose, esse sujeito é um criminoso inconsciente, contudo, o crime fruto de suas fantasias pode tornar-se real (TENDLARZ; GARCIA, 2013).

Alexander e Staub (1927), assinalam que devido aos motivos do crime neurótico serem de natureza inconsciente, a parte consciente de sua personalidade não influencia tais motivos, pois não são acessíveis a ela. Para o ato ser executado, o Ego é vencido por mecanismos neuróticos especiais e o Superego é "enganado", para que assim seja ocultado o sentido real da ação.

Por conseguinte Freud (1906), em sua conferência $A$ psicanálise $e$ a determinação dos fatos nos processos jurídicos, ratifica ao declarar que no neurótico seu segredo está oculto até para ele próprio e no criminoso o segredo está oculto somente para aqueles que o investigam e/ou interrogam. O pai da psicanálise aponta que o papel do terapeuta se assemelha ao do juiz de instrução ${ }^{1}$, haja vista ser necessário entender esse material

\footnotetext{
${ }^{1}$ Segundo TOURINHO FILHO (2003), em Processo Penal, caberia ao juiz de instrução colher as provas de um caso de infração, função que atualmente diz respeito a autoridade policial.
} 
psíquico oculto. Tendlarz e Garcia (2013), contribuem ao declarar que na visão psicanalítica, a culpa não é algo que seja reconhecida ou mesmo declarada pelo sujeito e nem mesmo identificada pelos investigadores do caso, a menos que eles tenham formação analítica para que realmente compreendam que a não declaração de culpabilidade não significa a ausência dela.

Assim, demostra-se a importância que seja destacado o processo da passagem ao ato. Dado que, é por meio desse mecanismo que o sujeito chega a consumação de seu ato criminoso - matar o outro - após seu agravamento, sendo esse o meio encontrado pelo sujeito de lidar com sua busca frustrada pelo objeto de completude.

\subsubsection{A busca por autopunição}

Como fora citado anteriormente, o sentimento de culpa que impulsiona 0 sujeito neurótico a efetuar o crime é originário do crime que fora cometido por ele enquanto infante - incesto e o parricídio. Mas o outro importante fator determinante para execução definitiva do ato é a busca por autopunição.

Freud (1928 [1927]), em Dostoievski e o Parricídio aduz a ambivalência de sentimento do menino para com a figura paterna durante Complexo de Édipo e aponta que a identificação com essa figura encontra no Ego um lugar permanente, estabelecendo-se como agente independente, e assim surge o Superego como herdeiro do Édipo. Essa estrutura assume para si a função que fora exercida pelo pai como atributos de crueldade, violência, etc. Freud ainda destaca (p. 113):

Uma grande necessidade de punição se desenvolve no ego, que em
parte se oferece como vítima ao destino e em parte encontra satisfação
nos maus tratos que lhe são dados pelo superego (isto é, no sentimento
de culpa), pois toda punição é, em última análise, uma castração, e,
como tal, realização da antiga atitude passiva para com o pai.

O pai da psicanálise assinala então o quão influente é a função paternal para o indivíduo, que em seu sentimento de culpabilidade por desejar a mãe, ambicionar a morte do pai e ser punido - castrado, leva consigo em sua constituição a necessidade de castigar-se. 
Assim como se relaciona com o que fora descrito por Alexander e Staub (1927), quanto ao neurótico e o Princípio de Talião, uma vez que, esse sujeito caracteriza-se por sua hipermoralidade, ou seja, há aqui a ação do Superego buscando seguir a lei, valores morais e as regras sociais, com consciência hipersensível e tendo como seu princípio dominante a justiça primitiva, isto é, essa herança punitiva que teve sua génese na castração e que atua nas tendências criminosas arcaicas, devido ao primeiro crime cometido pelo sujeito durante o Édipo.

No que tange a tendência neurótica a autopunição, sua busca por autocastigo é uma necessidade inconsciente que está relacionada a sua parte moral - Superego - e social do Ego. Freud, em seus estudos, pode concretizar a necessidade do neurótico com relação ao sofrimento, afirmando a satisfação do sujeito com relação a punição, sendo essa uma exigência moral (ALEXANDER; STAUB, 1927).

No entanto, Costa (2015), em estudo a obra freudiana, alude que a autopunição não está somente ligada ao prazer e satisfação, mas também à pulsão de morte, pois podem ser apontados dois lados: de um lado, Freud destacou a ação crítica, observadora e punitiva do Supergo sobre o Ego; e de outro lado, fenômenos como compulsão à repetição, reação terapêutica negativa e os sonhos traumáticos. Ou seja, o sujeito em sua autopunição não é regido somente pelo compromisso entre desejo e censura, mas também pela pulsão de morte, descrita por Laplanche e Pontallis (2001) como a forma do sujeito reduzir suas tensões, tendendo à autodestruição; o que pode contribuir para as condutas criminosas.

Cumpre ressaltar que, essa busca pela autopunição pode realizar-se de diferentes formas, mas é claro, com a mesma funcionalidade, abrandar a culpa. Destarte, percebe-se que a punição pode não ser autoinfligida, mas advindas da sociedade - prisões, penas de morte, etc., como no caso de muitos criminosos (FREUD, 1928 [1927]).

Alexander e Staub (1927, p. 62), apontam semelhanças entre dor e pena na forma de autopunir-se do neurótico e dos chamados criminosos neuróticos. Uma vez que, o "criminoso e a justiça, unidos, produzem o mesmo que o neurótico cumpre interiormente consigo mesmo: o delito e a pena." Na neurose 
a dor abre caminhos para a falta do sujeito, a satisfação por meio dos sintomas; com relação ao criminoso, a pena instituída ajusta-se a necessidade dos impedimentos morais. A pena infligida ao criminoso neurótico é a "condição necessária para a comissão das infrações, e em especial para repeti-las." Por isso, pode acontecer de o sujeito cometer vários crimes até que seja punido, e ainda assim, pode voltar a repeti-los ou até mesmo cometer crimes de outra ordem, na busca pela punição que atenuará sua culpa.

Então entende-se que o sentimento de culpa inconsciente e a busca por autopunição se correlacionam e são fatores de extrema relevância na execução do ato criminoso neurótico.

\section{Metodologia}

Para a concepção desse trabalho, realizou-se estudo de caso via literatura do "Caso Carlos in O Criminoso e Seus Juízes: A Partir De Um Ponto De Vista Psicanalítico" (ANEXO I), além da pesquisa bibliográfica que foi desenvolvida a partir de obras clássicas e publicações em plataformas eletrônicas, como Scielo, Pepsi e Google Acadêmico, com datas entre os anos de 2010 e 2020, com exceção de materiais que possuem dados de extrema relevância e indispensável corroboração para a pesquisa. Desse modo, essa pesquisa classifica-se como descritiva no que tange aos objetivos de estudo, e quanto à abordagem, possui caráter qualitativo com relação à compreensão sistemática dos conteúdos apresentados nesta pesquisa.

\section{Resultados e Discussão}

\subsection{Carlos: nuances de sua constituição}

O personagem dessa história verídica ocorrida em Berlim no ano de 1927 era Carlos, um jovem que ficou órfão de mãe desde muito pequeno. O menino fora criado por seu pai, no entanto, a presença do genitor não era tão frequente. Carlos participou da guerra e depois foi soldado, mais tarde, tendeu a bebida e as mulheres e vivia desempregado. A consequência de tudo isso na vida de 
rapaz foi que "sua preparação para vida fosse descuidada e que sua sorte depois não fosse muito esperançosa" (ALEXANDER; STAUB, 1927, p. 133).

Benvzik (2011), aponta o papel estruturante da figura paterna e a família como a base preparatória para inserção do sujeito na cultura, assim, entende-se algumas escolhas realizadas pelo rapaz, como, seguir uma profissão semelhante a que foi exercida pelo pai - um processo identificatório. Já quanto a mãe, para Cortes e Sirelli (2018), sabendo-se que quando a criança nasce sua mãe é seu primeiro objeto de amor, que é quem lhe direcionar todo o seu cuidado, amor e amparo, quando lamentavelmente ocorre a morte dessa figura materna ainda na infância, o infante tende a passar por um processo de luto ligado ao sentimento de desamparo, havendo então uma ilusão de abandono que relaciona-se com suas primeiras experiências narcísicas de onipotência, já que ele acreditava possuir esse objeto de amor - a figura materna.

Fica claro então, a relação de descuidado com a vida, que Carlos adota para si, uma vez que, passa pelo luto da perda materna e também pelo provável sentimento de desamparo referente à inconstância da presença paterna. Entende-se que, ele passa a buscar nas diferentes figuras femininas com quem se relaciona ao longo da vida, a substituição do seu primeiro objeto de amor perdido, apesar de não ser possível asseverar os reais impactos da perda materna na vida do rapaz, bem como, o desfecho de seu complexo edipiano.

Já quanto a sua tendência a bebidas, sabe-se que o neurótico obsessivo sofre de grande dispêndio mental devido sua consciência sobrecarregada de pensamentos constantes, muitos associados a conteúdos traumáticos e inconscientes, logo, pode-se perceber uma necessidade de se fugir da realidade, bem como, Freud (1924 [1923]) aponta que, o neurótico busca a substituição da realidade por algo mais aprazível, ou seja, a bebida exercia a função de substituição da realidade sofrível com que o rapaz lidava.

Tempos mais tarde o pai de Carlos casou-se novamente, e o rapaz nutria um desejo incestuoso pela madrasta, mas ao ouvir seus desejos inconscientes tão claramente expostos por seu pai, gerou uma reação repulsiva, por isso deixou de frequentar a casa paterna. Com isso, nota-se que ele estava revivendo a interdição da figura paterna novamente, ao impor-lhe a Lei da Castração, quando o pai confessa seu desagrado, ou seja, a Lei fora apresentada e ele se 
retirou. Freud (1940 [1938]), referiu-se aos múltiplos resultados da castração e o quanto isso poderia afetar a relação do filho com os pais e com seus futuros pares.

Bem como Alexander e Staub (1927), rememoram a seguinte frase em francês: "Il n'y que de la verité qui bless", que em tradução bem literal se aproximaria de "Só existe a verdade que dói", ou seja, esse ato revelador trouxe à tona toda a vulnerabilidade de Carlos. A fala do pai só lhe gerou sofrimento, repulsa e negação porque the apontou a verdade que para ele era absurdo admitir.

Diante de tais nuances que caracterizam brevemente a história de vida desse jovem, não pode-se passar desapercebido o contraste relacional entre todas as influencias constituintes de seu ser. Pois como já apresentado nesse trabalho, é de extrema importância o papel da organização familiar e inserção social para formação do sujeito. Mas ainda há alguns pontos relativos a história de Carlos que devem ser destrinchados até que se chegue ao seu ato final, o que será feito na próxima seção.

\subsection{Aspectos psicológicos envolvidos no assassinato}

Era noite em Berlim e a proposta era finaliza-la eternizando o amor de Carlos e sua amada no ato da morte, seria um suicídio duplo, mas tornou-se a tentativa de um homicídio. A noite terminou com a amada possuindo uma bala cravada em um de seus olhos, proveniente do disparo de uma arma de fogo, efetuado por seu parceiro; para Carlos a conclusão fora entregar-se à polícia em seu ato de autopunição.

Os traços da moça não passavam despercebidos, parecidíssima com a madrasta. Por esse motivo, não pode deixar de ser apontado que o sujeito busca em seu parceiro algo que Ihe remeta as semelhanças físicas e/ou relacionais com seus pais, isso é, uma forma de repetição de seu conteúdo mnêmicos (PAPALIA; FELDMAN, 2013). Destacando-se especificamente nesse caso, a relação de desejo de Carlos para com sua madrasta o que reflete em sua escolha objetal posterior. 
Frisando que, tal relacionamento só ocorrerá a partir da cena que o pai Ihe expos seus reais desejos para com sua atual esposa, desde então, o rapaz estabeleceu uma relação duradoura com sua amada, que tinha certo ar maternal, realizando muitos de seus desejos e sempre muito cuidadosa com ele. Se assemelhando com os cuidados maternos, bem como os prestados por sua madrasta. O fato da amada estar prometida em casamento para um outro homem, não os impediu de viver o romance, pelo contrário, seria esse o "suposto" motivo que desencadeou a tentativa de duplo suicídio, no entanto, os demais fatos nos dizem outras coisas.

Por isso, Severo (2014) destaca o fato de todos virem ao mundo sucedendo gerações e tendo o papel de assegurar a continuidade da transmissão de valores, ideias e algo da cultura familiar que possa ser até inconsciente. Também por esse motivo, não podemos deixar de apontar a eleição do par amoroso, que tudo tem a ver com o compromisso entre os desejos adultos e infantis, levando muitas vezes para o matrimonio ideais parentais, que como declara Losso (1998, apud SEVERO, 2014), o casal se constitui a partir de partes adultas e também das mais arcaicas do funcionamento psíquico do indivíduo.

Imperioso ressaltar que em certa ocasião, já desenganados de viverem o romance na integra, a moça sugere a Carlos que ela se case e ele seja "amigo da casa", ou seja, sugeriu que mantivessem o relacionamento após seu casamento, só que com o rapaz então ocupando o lugar de seu amante. Esse lugar de terceiro na relação, foi de encontro diretamente com a culpa inconsciente de Carlos por seus crimes ancestrais (ALEXANDER; STAUB, 1927, p. 135).

Pizutti (2012), declara a importância do Complexo de Édipo no processo de instauração da lei paterna e construção do Supergo, lembrando que com a lei instaurada o sujeito passa a uma condição de sujeito do desejo e também de neurose. Já Markus (2015), traz uma brilhante contribuição ao afirmar que a partir desse complexo ganha-se sentindo esse lugar ocupado por um terceiro, ou nesse caso, o lugar ocupado por Carlos na relação entre seu pai e madrasta e posteriormente entre sua amada e seu noivo, sempre ocupando esse terceiro lugar. 
Segundo Markus (2015), tomando como base a obra lacaniana, na primeira situação, assim como ocorre no exercício da função paterna, o pai do jovem o impõe seu lugar mediante a apresentação da lei paterna - Nome do Pai - que quebra a simbiose entre mãe e filho, nesse caso, entre seu filho e a madrasta. Carlos então no campo de sua neurose, torna-se sujeito de desejo em busca do substituto de seu objeto de desejo anterior, encontrando assim sua amada. No entanto, lhe era insuportável conviver com a culpa ao passo que essa cena incestuosa em que ele ocupara novamente o lugar de terceiro não se concretizava tão conscientemente, mas com o enlace matrimonial da moça, porém, ver-se novamente ocupando esse lugar que não lhe era suportável.

Um dos fatores determinantes para que o crime ocorresse foram as respostas a rigorosidade do Superego do jovem Carlos. De Oliveira (2018), aponta que certas manifestações psíquicas estão sobre o controle do supergo, que é uma instância portadora da Lei e funciona como a consciência moral do indivíduo. É portanto, para a psicanálise freudiana, uma consciência especial que atua a partir do exercício da censura que ocorre através das pulsões recalcadas sobre as pulsões sexuais resultando em uma ansiedade egoíca que culmina em um sentimento inconsciente de culpa (FREUD, 1910).

Segundo Freud (1923), essa instância psíquica herda do complexo edípico também as funções de proibição como resultado da Lei que Ihe fora imposta, que quão mais forte for o complexo e mais rápida sua repressão, que para ocorrer tem influência social, cultural, religiosa, escolar, etc., mais severamente o superego assumirá o domínio do ego, caracterizando então um superego rígido que resulta em uma consciência moral também rígida ou um sentimento de culpa inconsciente.

Um outro fator que também contribuiu para que o crime ocorresse, foi a quanto a simbolização de seus conteúdos inconscientes, o que Carlos não conseguiu realizar. Lacan (1998, p. 251) refere-se a esse processo de elaboração dos conteúdos psíquicos que constroem a história de vida do sujeito e então tornam-se familiares ao serem abordados em discurso e assim introduzido no campo simbólico, é "[...] neste trabalho que faz de reconstruí-la [a obra do seu ser] [...]" Há partindo desse ponto, uma reconstrução da obra criada pelo sujeito - sua história de vida. O psicanalista ainda relata que em processo 
analítico, quando o analista oferta respostas ao apelo do analisando, o sujeito pode frustra-se, pois é através da linguagem, ou seja, de sua própria fala, que ele começa a compreender acerca de sua obra e que também é possuidor de um campo imaginário. Havendo frustração e sendo então desvendadas as intenções imaginárias por trás do discurso do sujeito, a resposta pode manifestar-se através da agressividade, como ocorrerá com o rapaz.

Como já supracitado neste trabalho, quando o sujeito não obtém recursos suficientes que lhe possibilitem a inserção no campo da linguagem pode-se atingir o ponto que em ele passe ao ato, para que então consiga lidar com sua angústia e sentimento de culpa inconsciente. Pinheiro (2011), afirma que ao sentir-se ameaçada ou frustrada em sua imagem, a pessoas pode agir agressivamente, inclusive em ações. Portanto, percebe-se alguns dos fatores que tiveram enorme relevância para Carlos cometesse a tentativa de homicídio.

\section{Conclusão}

Em vista do exposto, pode-se entender que vários foram os fatores que contribuíram para o desfecho do crime realizado pelo rapaz, muitos deles aqui não caberiam ser mensurados até mesmo devido a inexistência de maiores informações e maior aprofundamento no histórico de vida dele.

Todos os fatos ocorridos na vida de Carlos, desde a tenra infância, culminam na história de vida de um jovem angustiado em sua neurose e sentimento de culpa inconsciente. Apresentou-se como um homem padecido devido seus episódios de perdas e sentimentos de abandono, aprisionado em seu sofrimento. Quanto a morte da mãe quando ele ainda era um garotinho, não se pode asseverar os reais danos e meios que ele possa ter buscado para simbolizar ou não, mas já quanto a ausência frequente de seu pai, muito demonstrou-se através da identificação de Carlos quanto a profissão que exerceu por algum tempo, seus momentos de humor deprimido e sua entrega a uma vida sem norte, tendendo ao uso de álcool e relacionando-se 
amorosamente com diferentes mulheres, sem um compromisso fixado, até encontrar sua amada.

O relacionamento estabelecido com a madrasta obteve valor inestimável para que Carlos então enamorado por ela, frustrado por ter que se afastar e ainda tendo expostas suas verdadeiras intenções através da interdição paterna, fosse em busca de um objeto para destinar seu investimento psíquico. No entanto, sabe-se que a única moça com quem ele tinha se relacionado de forma mais séria e duradoura, era dotada de atributos físicos inegavelmente semelhantes aos de sua madrasta, ou seja, o que fora buscado de forma inconsciente, já que tratou-se de um investimento objetal referenciando-se em seu enamoramento.

Mas é evidenciado que o ponto chave para o desfecho criminoso, relaciona-se com o fato de lhe ter sido sugerido tornar-se amante de sua então namorada que se casaria com outro. Entende-se então, que Carlos ao perceberse tão conscientemente ocupando o lugar de terceiro na relação com sua amada, não obteve êxito em simbolizar tal narrativa que remetia ao seu crime ancestral de incesto e nem mesmo trouxe sua obra de vida para o campo da linguagem, perdurando em seu sofrimento e inegável angústia. Essa verbalização mostrase importante de tal modo que, bem como apontado por Lacan (1986), é através da verbalização que o homem integrasse a um sistema simbólico, o que possibilita seu desenvolvimento enquanto sujeito.

Houve portanto, além do exposto, uma regressão a cena edipiana de tal modo que matar a moça seria a forma encontrada pelo rapaz para assim obter êxito em uma cena que se assemelhava ao enredo do Complexo de Édipo, uma vez que, ao matar sua amante o rapaz estaria matando nela a figura de sua madrasta, a mulher a quem ele de fato desejava possuir, e então vencer o seu pai nessa disputa, já que ela representava um papel substituto à figura materna, ou nesse caso, a madrasta. Já o ato de suicidar-se - que não chegou as vias de fato, representaria o parricídio então concluído, já que nessa cena, Carlos ocupava simbolicamente o lugar de seu pai.

Ele então em sua busca por alívio das tensões e angústia provenientes do sentimento de culpa inconsciente que o assolava, obteve por meio da passagem ao ato, realizando o crime de tentativa de homicídio, sua válvula de 
escape e também sua autopunição, visto que, o próprio rapaz fora quem entregou-se para as autoridades confessando o crime, mas ainda assim buscando um motivo que soa-se plausível para sua consciência e também para a sociedade, uma vez que, segundo ele o crime era associado ao fato de tentar livrar sua amada de uma vida insatisfeita ao lado de seu futuro marido.

Mas há também uma última ressalva, devido ao fato dessa trama verídica, finalizar-se com amante - ou seja, a figura representativa da mãe ou no caso madrasta - como a vítima, entende-se também que Carlos além de um sentimento de identificação para com seu pai, nutria um desejo objetal. Pois concluiu sua missão de separar simbolicamente a figura materna e paterna e então ter a atenção do progenitor voltada para si, o que justifica-se no fato de durante toda sua vida o rapaz dividir a atenção e amor do pai. Primeiramente com mãe, depois com seus vários compromissos, o trabalho e por fim com a madrasta. Segundo Freud (1932 [1933]), a identificação com o objeto - figura paterna - é diferente da escolha do objeto, para exemplificar o autor declarou que quando o menino destina ao pai sua escolha objetal, ele quer tê-lo para si, possuí-lo. Diferente do primeiro, que seria desejar ser como a figura de identificação.

Conclui-se então, que a culpa e a busca por autopunição são fatores associados e determinantes quando relacionados ao ato criminoso, 0 assassinato cometido pelo neurótico. Sendo a culpa oriunda do Complexo de Édipo e a autopunição originada do Complexo de Castração. Por conseguinte, esse sujeito tido como criminoso ancestral, isto é, desde sua infância, carrega consigo o sentimento de culpa e deseja ser punido por seu crime original, buscando essa pena posteriormente em situações substitutivas a vivenciada enquanto criança.

\section{Referências}

ALEXANDER, Franz; STAUB, Hugo. O criminoso e seus juízes: a partir de um ponto de vista psicanalítico (1927). V. 2. Curitiba: Íthala, 2016

BARRETTA, João Paulo Fernandes. O complexo de Édipo em Winnicott e Lacan. Psicologia USP, v. 23, n. 1, p. 157-170, 2012. 
BENCZIK, Edyleine Bellini Peroni. A importância da figura paterna para o desenvolvimento infantil. Rev. psicopedag., São Paulo , v. 28, n. 85, p. 6775 , 2011.

Disponível em <http://pepsic.bvsalud.org/scielo.php?script=sci_arttext\&pid=S010384862011000100007\&lng=pt\&nrm=iso >. acessos em 21 jul. 2020.

CALAZANS, Roberto; BASTOS, Angélica. Passagem ao ato e acting-out: duas respostas subjetivas. Fractal, Rev. Psicol., Rio de Janeiro , v. 22, n. 2, p. 245256, Aug. 2010 Available from <http://www.scielo.br/scielo.php?script=sci_arttext\&pid=S1984-

$02922010000800002 \&$ lng $=$ en \&nrm=iso $>$. access on

Nov. 2020. https://doi.org/10.1590/S1984-02922010000800002.

CORTES, Ilana; SIRELLI, Nilda Martins. A criança e o luto: a vivência da morte na infância. Psicanálise \& Barroco em Revista, v. 14, n. 2, 2018.

COSTA, Carlos Alberto Ribeiro. A metapsicologia da autopunição: revisitando os 'criminosos por sentimento de culpa'. Cad. psicanal., Rio de Jeneiro, v. 37, n. 33, p. 85-104, dez. 2015 . Disponível em <http://pepsic.bvsalud.org/scielo.php?script=sci_arttext\&pid=S1413-

62952015000200005\&lng=pt\&nrm=iso >. acessos em 27 ago. 2019.

DE ALMEIDA, Alexandre Mendes. O desejo no neurótico obsessivo. Psicologia Revista, v. 19, n. 1, 2010.

DE OLIVEIRA, Luzia Carmem. A Constituição do Ego e Superego na Teoria Freudiana, que Lugar para a Educação?. In: Congresso Brasileiro de Psicologia da FAE. 2018. p. 223-230.

ELIA, Luciano. O conceito de sujeito. Psicanálise passo a passo. 50. ed. Rio de Janeiro: Jorge Zahar, 2004.

FREUD, Sigmund. A interpretação dos sonhos (Primeira parte - 1900). ESB Vol. IV. Rio de Janeiro: Imago, 1996

FREUD, Sigmund. A psicanálise e a determinação dos fatos nos processos jurídicos (1906). "Gradiva" de Jensen e outros trabalhos (1906-1908). ESB Vol. XIV. Rio de Janeiro: Imago, 1996, p. 54-63

FREUD, Sigmund. Alguns tipos de caráter encontrado no trabalho analítico: Criminosos em consequência de um sentimento de culpa. (1916). A História do Movimento Psicanalítico, Artigos sobre a Metapsicologia e outros trabalhos (1914-1916). ESB Vol. XIV. Rio de Janeiro: Imago, 1996, p. 201-202

FREUD, Sigmund. Conferências introdutórias sobre psicanálise (Parte III) (1916-1917). ESB Vol. XVI. Rio de Janeiro: Imago, 1996

FREUD, Sigmund. Dostoievski e o Parricídio (1928 [1927]). O Futuro de uma Ilusão, O mal-estar na civilização e outros trabalhos (1927-1931). ESB Vol. XXI. Rio de Janeiro: Imago, 1996, p. 106-119 
FREUD, Sigmund. Moisés e o monoteísmo, Esboço de psicanálise e outros trabalhos (1937-1939). Esboço de Psicanálise (1940 [1938]). ESB Vol. XXIII. Rio de Janeiro: Imago, 1996.

FREUD, Sigmund. Novas conferências Introdutórias à Psicanálise (1932-1936). Dissecção da personalidade psíquica (1932 [1933]). ESB Vol. XXII. Rio de Janeiro: Imago, 1996.

FREUD, Sigmund. O Ego e o ID e outros trabalhos (1923-1925). ESB Vol. XIV. Rio de Janeiro: Imago, 1996.

LACAN, J. O seminário, livro XV (1967-1968): o ato psicanalítico, inédito, Jorge Zahar, 1990.

LACAN, J.; SEMINARIO, X. A angústia (1962-63). Rio de Janeiro: Jorge Zahar, 2005.

LACAN, Jacques. (1986). Seminário 1. Os Escritos Técnicos de Freud. Rio de Janeiro : ed. Jorge Zahar.

LACAN, Jacques. (1998). "Função e Campo da Fala e da Linguagem em Psicanálise". In: Escritos. Rio de Janeiro : ed. Jorge Zahar.

LACAN, Jacques. O seminário livro 4: A relação de objeto (1956-57). Rio de Janeiro, Jorge Zahar Ed., 1995.

LINS, Tatiana; RUDGE, Ana Maria. Ingresso do conceito de passagem ao ato na teoria psicanalítica. Trivium, Rio de Janeiro , v. 4, n. 2, p. 12-23, dez. 2012 Disponível

em

<http://pepsic.bvsalud.org/scielo.php?script=sci_arttext\&pid=S2176-

$48912012000200003 \&$ lng=pt\&nrm=iso>. acessos em 18 out. 2019.

MAGALHÃES, Andrea Seixas; FÉRES-CARNEIRO, Terezinha. Conquistando a herança: sobre o papel da transmissão psíquica familiar no processo de subjetivação. Família e casal: efeitos da contemporaneidade, p. 24-32, 2005.

MAGALHÃES, Belmira; MARIANI, Bethania. Processos de subjetivação e identificação: ideologia e inconsciente. Linguagem em (Dis) curso, v. 10, n. 2, p. 391-408, 2010.

MARKUS, Catiúcia Hardt Mayer. Histeria masculina. 2015.

PAPALIA, D. E. e FELDMAN, R. D. (2013). Desenvolvimento Humano. Porto Alegre, Artmed, $12^{\underline{a}}$ ed.

PASSOS, Maria Consuêlo; POLAK, Pia Maria. A identificação como dispositivo da constituição do sujeito na família. Mental, Barbacena , v. 2, n. 3, p. 3950, nov. $2004 \quad$ Disponível em <http://pepsic.bvsalud.org/scielo.php?script=sci_arttext\&pid=S167944272004000200004\&lng=pt\&nrm=iso >. acessos em 24 set. 2019

PINHEIRO, Débora Patrícia Nemer et al. Três casos de parricídio? Passagem ao ato em diferentes configurações psicopatológicas. Psicologia Clínica. 
Pontifícia Universidade Católica de São Paulo, SP.(tese de doutorado), 2011.

PIZUTTI, Jaqueline Machado. A constituição do sujeito na psicanálise. 2012.

POLETTO, Michele. NEUROSE E PSICOSE: semelhanças e diferenças sob a perspectiva freudiana. Psicanalise \& barroco em revista, v. 10, n. 2, 2019.

PONTALIS, Jean-Baptiste; LAPLANCHE, J. Vocabulário da psicanálise. São Paulo: MartinsFontes, 2001

RINALDI, Doris. Culpa e Angústia: algumas notas sobre a obra de Freud. Rio de Janeiro.(No prelo), 2014.

ROUDINESCO, Elisabeth. Dicionário de psicanálise. Rio de Janeiro: Zahar, 1998.

SALUM, Maria José Gontijo. Considerações sobre a passagem ao ato, o actingout e o crime. Instituto de, 2009.

SANTANA, Guilherme; DA SILVA, Jerto Cardoso. Abordagem psicanalítica de um caso de neurose obsessiva. Boletim Entre SIS, v. 3, n. 1, 2018.

SEVERO, Ariane. O suave mistério amoroso: psicanálise das configurações vinculares / Ariane Severo. - 1.ed. - Porto Alegre, RS: AGE, 2014

TENDLARZ, Silvia Elena; GARCIA, Carlos Dante. A quem o assassino mata? O serial killer à luz da criminologia e da psicanálise. São Paulo: Editora Atheneu, 2013.

TOREZAN, Zeila C. Facci; AGUIAR, Fernando. O sujeito da psicanálise: particularidades na contemporaneidade. Revista Subjetividades, v. 11, n. 2, p. 525-554, 2016.

TOURINHO FILHO, Fernando da Costa. Processo penal, vol. 1. São Paulo: Saraiva, v. 21, 2003. 
ANEXO I

III

\section{TENTATIVA DE HDMICÍDIO DE UM NEURÍTICD}

Uma noite do inverno de 1927, Carlos, de vinte e cinco anos de idade, vendedor, desempregado, e sua amante, empregada doméstica, alugaram, por algumas horas, um quarto de hotel em Berlim. Quando ambos estavam sós, Carlos atirou nela com um revólver, ferindo-a no crânio, e sofreu um desmaio, pedindo auxílio depois de haver se recuperado. A polícia o prendeu. Aconteceu que os amantes tinham decidido se suicidar juntos, reunindo-se aquela noite para esse fim. Antes tinham percorrido bares e estabelecimentos de diversão e escrito cartas de despedida. A arma foi comprada com dinheiro da garota. Já no trance do suicídio, depois do Carlos disparar sobre ela, não teve a coragem de virar a arma contra si mesmo e preferiu se entregar às autoridades. A amante ficou caolha como resultado do disparo.

Parece que o ato não tinha motivos manifestos. Carlos era jovem, saudável, um pouco dado ao álcool e às mulheres, mas de caráter tranquilo, no geral. Sua mãe morreu sendo ele pequeno. Seu pai foi um oficial e esteve na linha de frente durante a guerra. Depois, por causa da sua profissão de engenheiro, estava sempre fora de casa. Carlos tinha participado, ainda muito jovem, na guerra e na proteção das fronteiras, depois, como soldado. Tudo isso junto tinha feito com que sua preparação para a vida fosse descuidada e que sua sorte depois não fosse muito esperançosa. Teve que tornar-se vendedor, encontrando emprego com interrupções. A maior parte do tempo estava sem trabalho e vivia do subsídio de desemprego e de alguns trabalhos ocasionais. Contudo, suas tribulações não eram excessivas. A amante, que descendia de uma boa família de pequenos burgueses provincianos, conheceu Carlos uns meses antes e ambos se engajaram em atividades amorosas. Estava a serviço de uma família no bairro do 
Oeste - bairro de gente abastada - em Berlim. Era noiva precisamente de um paisano com quem seus pais queriam casá-la. Carlos sabia disso. Uma vez que lhe perguntou se não preferiria casar com ele, ela lhe declarou que tinha muita vontade de fazê-lo, mas que precisava ter uma profissão fixa para poder mantê-la e gostar menos de bebida e ser menos mulherengo. De todas as formas, o noivado com o homem do vilarejo não foi obstáculo para a continuação das relações entre nossos personagens. Como ele não tinha dinheiro, ela era quem pagava os custos dos passeios comuns e os ingressos do cinema. Ele suportava tudo e aceitava também a ideia de que ela fosse a noiva de outro, pensando que teria que casar com esse homem por coerção dos pais, que, de outra forma, a expulsariam de casa e a deserdariam, e que ela, sem dúvida, lhe preferiria se pudesse manter uma casa. Contudo, o equilíbrio entre os amantes começou a se perturbar, e o mau humor de um desatava uma depressão no outro. Estas alternâncias de sentimentos revelavam, parece, o efeito das oscilações dela entre seu noivo oficial e o amante. Um dia ela disse ao Carlos que seria melhor ela casar com o noivo e que ele poderia ser o "amigo da casa". Carlos rejeitou de forma veemente tal oferta, que lhe parecia completamente inadmissível do ponto de vista moral, sem discussão. A consequência imediata foi um estado depressivo, que deixa entrever pensamentos suicidas. Carlos lhe disse que quer por fim à sua vida, da que está cansado, porque não vale para nada, nem sequer é capaz de fundar uma família nem de ter um lar e lhe pede que o acompanhe a morrer. Ela, por sua parte, também é muito infeliz. Vão casá-la à força com um homem que não quer, e, embora acredite que faria o possível para cumprir seus deveres de esposa, seria às custas da sua infelicidade. Também, no geral, está cansada da vida. Seus pais e irmãos não se preocupam com ela e a maltratam. Uma irmã mais velha acusou-a um dia, sem motivo, de um furto. Por tudo, prefere juntar-se a ele na morte. O pensamento dele é logo capturado e se presta a redimir sua amante de uma vida triste e de um porvir infeliz. Com isso decidem o duplo suicídio. 
Precisa dizer que os motivos conscientes de Carlos e da sua amante não podem ser os verdadeiros e decisivos? O motivo que Carlos enuncia para o homicídio dela se reconhece facilmente como uma racionalização superficial, que serve para ocultar outros motivos determinantes reprimidos, mas eficazes. Também é rara a ocasião que faz nascer nele a resolução para o suicídio. Manteve relações com a garota, sabendo que era noiva de outro e, repentinamente, sem transição, desemboca em uma reação defensiva, veemente e afetiva à ideia de que a jovem tem que casar com outro e que ele terá que tornar-se o "amigo da casa". De fato, não se lhe exige nada diferente do que tinha feito até então, e, por tanto, não se compreende como a proposta provocou o fato.

Pela experiência psicanalítica sabemos que a situação de "amigo da casa" tem a significação inconsciente de um delito de Édipo realizado. Um terceiro, sem ter o direito, possui ilicitamente uma mulher que pertence a outro: o marido legítimo. Isto é o que a criança deseja em seu complexo e o que esta situação significa para Carlos. Sua mãe tinha morrido quando ele era muito pequeno. A forte amnésia que esconde sua infância remota não podia ser suprimida, no essencial, pela situação desfavorável exterior. Sua atitude com o pai era positiva às vezes, mas frequentemente rebelde. Ass vezes morava com ele, outras ia embora ou se embravecia com ele. Uma profunda indiferença dominava esta relação sentimental. Quando o pai, já sexagenário, casou com uma jovem de idade semelhante à do seu filho a relação pareceu melhorar. Logo se desenvolveu uma íntima camaradagem entre a madrasta e Carlos. A prevenção contra a madrasta, tão frequente, faltava completamente. Ao contrário, Carlos se sentia cada vez mais atraído por ela, que também lhe professava amizade, até o ponto de melhorar como nunca as relações do jovem com a família paterna, de tão tensas como haviam chegado a ser. Nesse tempo, a esposa do pai, que tinha uma constituição débil e susceptível às doenças, sofreu uma doença aguda que a obrigava a ficar na cama. Carlos, enquanto o pai tinha que ficar o dia inteiro fora da casa por causa dos seus afazeres, ficava feliz de poder tratar e cuidar da madrasta. Preparava e dava-lhe 
os alimentos, e conversava com ela, até o pai regressar à noite. Nessa hora, Carlos ia embora e dormia fora da casa paterna.

Um dia o pai lhe disse, subitamente, que seria melhor que não aparecesse pela casa durante sua ausência, porque as pessoas podiam pensar mal e fofocar. Esta cuidadosa consideração, compreensível e adequada à situação real, produziu no garoto um grande abatimento. Sentia-se enormemente maltratado pelo pai com uma suspeita tão injusta, como se seu pai lhe houvesse golpeado na cabeça, acreditando isso dele. A consequência foi evitar totalmente a casa paterna, à qual não voltou até a morte da madrasta, acontecida uns meses mais tarde.

Surpreende esta reação sentimental tão inesperada e violenta e tão pouco adequada à realidade dos fatos. Espontaneamente vem à nossa memória o provérbio francês Il n'y a que de la verité qui blesse. Embora nenhuma circunstância indicasse que se lhe pudessem reprochar a Carlos desejos pecaminosos conscientes a respeito da sua madrasta, contudo, nos consta, com base na nossa experiência psicanalítica, que podia sentir-se tão ferido pelas palavras do seu pai porque este tinha lhe atingido no ponto mais vulnerável, falando às claras de algo que, embora o jovem não tivesse desejado conscientemente, tinha desejado de uma maneira instintiva no seu inconsciente. Nosso sujeito, que antes tinha tido incontáveis relações amorosas de curta duração e, por tanto, nunca tinha chegado a focar essencialmente seu sentimento amoroso em uma mulher determinada como objetivo, engaja-se, a partir desta cena com o pai, em uma relação duradoura com sua amante até o momento da ocorrência. A jovem tem a mesma idade que a madrasta, o mesmo tipo físico e uma semelhança exterior que não passa inadvertida às ingênuas testemunhas no fórum. Também era semelhante à sua madrasta na situação externa da sua vida, porque do mesmo modo pertencia a um terceiro, o noivo, com quem devia se casar. E em outros aspectos, sua relação com Carlos tinha certo ar maternal. Ela era sempre quem o convidava; em certa ocasião proporcionou um emprego a um irmão de Carlos; aparecia sempre lhe dando algo, enquanto ele recebia os benefícios da relação, 

relação com a madrasta. Assim, realiza, com a querida, o que inconscientemente tinha desejado fazer com aquela.

Agora podemos compreender a igualdade de sua reação depressiva perante a advertência do pai para evitar boatos e perante a proposição da sua amante de tornar-se o "amigo da casa", porque sua situação psíquica perante a madrasta e perante sua amante era a mesma. Seu afeto para a mulher do seu pai, excepcionalmente forte se o comparamos com seus outros afetos, se fundamenta em seu desejo incestuoso inconsciente. Estava em jogo um Superego robusto e bem dotado de força impeditiva, que proibia o tal desejo de tornar-se consciente e poder-se realizar. Por isso é tão susceptível a advertência do pai, que coloca em risco a obra repressora de tornar inconsciente este desejo, obra que é cada vez mais difícil. E então tenta se livrar do seu sentimento inconsciente de culpa, espreitando até aquele momento, e da tensão de seu ânimo, mediante uma projeção. As exortações do seu pai ficam deformadas, opinando que lhe reprocha algo que não fez e que é injusto, por tanto, com ele. Desta forma consegue se afastar do pai e colocá-lo em uma situação de injustiça. $\mathrm{Na}$ verdade, o pai não lhe havia reprochado conscientemente seu desejo incestuoso. Foi Carlos quem deu às palavras esse sentido, adequado a seus anseios inconscientes. Como na maior parte das projeções, é possível que o afeto projetado acerte no inconsciente do pai, já que na sua advertência podiam se manifestar seus próprios ciúmes inconscientes contra o filho. A reação afetiva, inexplicável pelos conteúdos anímicos conscientes, ganha todo o sentido se escutamos o diálogo de ambos os inconscientes, o filial e o paterno.

Mesmo que com esta projeção de culpa tivesse fugido da tensão da sua consciência, seus desejos incestuosos inconscientes ainda não calavam. Pelo contrário, seria possível que se tornassem mais fortes porque a força impeditiva do seu Superego tinha se debilitado ao suprimir os sentimentos de culpa. As relações com a amante aparecem como uma tentativa inconsciente para resolver a tensão dos seus 
instintos, cedendo perante a tendência saudável de eleger um objeto exógamo, embora nesta solução destaque o desejo incestuoso, ao reunir o objeto elegido todas as características da mãe proibida. A proposição da amante de casar com seu noivo, ficando Carlos como "amigo da casa", produz neste uma recaída em seus sentimentos de culpa. Até então, lhe tinha sido possível, à custa de infinito cuidado e muito esforço, manter adormecidas suas instâncias impeditivas, já que a querida, na verdade, não era sua mãe, mas um objeto alheio, cujo amor estava permitido, vencendo e perdurando deste modo as tendências incestuosas tingidas do Isso. Porém, perante a ameaça de se tornarem conscientes os motivos verdadeiros das suas relações com a querida, ao ser perturbada a obra repressora, tinham que ressurgir robustecidos os sentimentos de culpa. Seu equilíbrio psíquico podia se manter melhor ou pior enquanto a garota não estivesse realmente casada e, vivendo separada do noivo, declarasse que queria casar com Carlos e não com o outro. Um matrimônio que completasse, para o inconsciente, o fato incestuoso, não lhe resultava suportável. A resolução de matá-la e se suicidar é a tentativa de resolver de uma maneira explosiva, cortando-o, o estado de tensão, cujo sentido mais profundo logo se tornará compreensível.

Em primeiro lugar, o sujeito vive, sublimando-o perante sua madrasta, um violento desejo incestuoso, proveniente do complexo de Édipo, não superado, cuja existência a respeito da verdadeira mãe certamente não podia ser comprovado, mas que, contudo, existiu indiscutivelmente como se deduz das experiências psicanalíticas e do total comportamento psíquico de Carlos. Quando se fecha este escape, ao impedirem as palavras do pai à obra repressora, os desejos incestuosos se transplantam a um objeto subsidiário e, ao ruir esta postura dos desejos reprimidos, se verifica uma regressão à fase sádico-masoquista. $\mathrm{O}$ incesto, proibido pela consciência, é representado pela morte comum. De acordo com sua sintomatologia histérica, esta morte significa ao mesmo tempo o auto castigo e a satisfação de desejos eróticos. A expressão usual unidos na morte mostra a ênfase erótica da ideia da morte comum. E se torna possível o desencadeamento 
do impulso incestuoso, já que a pena capital ditada contra si mesmo apazigua qualquer sentimento de culpa.

A proposta da querida de casar com o noivo pode ter originado, ademais, uma depressão no jovem, porque tal ideia representava a vitória do modelo paterno. Assim, a resolução de matar a garota significa uma tentativa de roubar a mulher do pai. Por isso, o fato contem os dois componentes da situação edípica: tirar a mulher do pai e unir-se a ela.

Mas isso não é suficiente para explicar como Carlos pôde realizar o fato sem remorso, que é o problema principal, embora tenhamos podido compreender algo dos motivos inconscientes. A ação deve ter tido, ainda, para ele, um sentido inconsciente respondendo às exigências de um Superego rigoroso demais. De outra forma não seria compreensível que depois de ter lesionado sua amante, se esquivasse do suicídio e não tivesse remorso depois, mas, pelo contrário, acreditasse ter agido bem. Esta estranha conformidade subjetiva do Superego com o fato, baseada em acontecimentos inconscientes, é sumamente interessante na psicologia de tais casos, porque apenas a compreensão desse processo inconsciente de justificação pode nos explicar como pessoas dotadas de sentimentos morais podem delinquir tão gravemente sem sentimentos de culpa.

A forte influência do reproche interior em todas as ações de Carlos é indicado pelo fato de que os sentimentos de culpa pelos seus desejos incestuosos lhe conduziram a uma vida intranquila, desterrando-o da casa paterna e tornado-lhe impossíveis as relações normais com sua amante. Às repetidas perguntas sobre o motivo que teve para acabar com a vida da jovem e dele próprio, dá uma resposta estereotipada, invariável: "Vi o matrimônio do meu irmão mais velho - Carlos é o mais jovem de ambos - e enquanto meu irmão trabalha o dia inteiro e obtém muito dinheiro da sua elevada colocação, sua mulher fica sempre deitada e pensa apenas em presumir, enganando-o e dilapidando o dinheiro, até o ponto de que o matrimônio não pode ser mais infeliz. Eu quis poupar a minha amada de um matrimônio 
parecido". Espantosa a cegueira lógica desta argumentação. No caso que cita como exemplo, o homem é o prejudicado e se acumula toda a culpa sobre a esposa infiel. $\mathrm{O}$ argumento seria válido apenas se estivesse apaixonado de uma mulher má e revela assim a intenção de matar uma mulher deste tipo. Devemos lembrar que a amante, de fato, tinha levado má vida, gastando seu dinheiro e enganando o noivo com outro homem, que precisamente era Carlos, por quem fez tudo o que ele esperava da sua madrasta e que lhe produzia os sentimentos inconscientes de culpa. Por tanto, matando-a se identificava, para começar, com o homem ofendido e finalmente com seu pai, que matando vinga a infidelidade cometida. A amante e a madrasta estavam tão identificadas em seu inconsciente, que podia matar a madrasta na amante, como se aquela, e não outra, tivesse sido infiel ao pai. Desta forma, pode representar o papel do pai vingador. Os remorsos pelo incesto cometido se suprimem por esta identificação com o pai e assim se conciliam o Superego com o Isso e consegue que o fato ganhe um aspecto positivo, aliviando seu remorso, ao vingar no lugar do pai a enganação da esposa. Aqui há também uma projeção de culpa. Os próprios desejos incestuosos, sentidos para com a madrasta, se projetam sobre a amante como objeto substituto. E por isso pode se livrar de seus sentimentos de culpa, matando no papel do pai ultrajado a esposa infiel.

Também é significativo que a amante, em seu inconsciente, compreendesse o fato como um ato de vingança. Depois do acontecido, a jovem se mostrava sumamente indignada com Carlos, a quem tentou prejudicar por todos os meios, declarando na investigação que ela não deu seu consentimento para ser morta, mas que ele quis assassiná-la à força. Só no juízo oral desistiu da sua atitude hostil, perante o peso esmagador das declarações das testemunhas e a leitura das cartas que tinha escrito, acabando por confessar a verdade. Estranho comportamento que resulta compreensível se pensarmos que significa a reação instintiva perante o matiz agressivo da ação, percebido inconscientemente por ela. 
Estes motivos, que atuam dinamicamente no inconsciente do sujeito, nĩo podem se exteriorizar em fatos sem ter ganhado também o Eu consciente mediante racionalizações sobre a ação, e por isso Carlos convence seu Eu consciente de que, livrando sua querida das enganações, misérias e tribulações da existência, realiza uma boa nçĩo.

Com a resolução de se suicidar pretende o logro do seu desejo edípico na sua fase sadomasoquista: quer se unir na morte com sua amante e, ao mesmo tempo, suprimir os remorsos, se identificando com o pai ultrajado, que mata o filho culpado de incesto.

A última determinação que implica o pensamento do suicídio se refere ao desejo de Édipo levado ao seu extremo. Se matando, mata o pai com o qual tem se identificado. Identificação que se verifica em primeiro lugar a respeito da mulher. $O$ homem dono da mãe deve morrer. O suicídio significa, além disso, a supressão do Superego e, ao mesmo tempo, do pai nele imiscuído, de onde emanam os sentimentos de culpa, que o ameaçam, e que serão forçados a calar pelo seu suicídio. Com razão Freud considera todo suicídio como o assassinato simbólico de um terceiro, intruso na personalidade do suicida.

Só nos resta averiguar as circunstâncias que impediram a Carlos a consumação da sua própria morte. Devemos advertir que seus sentimentos de culpa, depois do acontecido, não eram excessivos. Sentia-se quase no direito de ter procedido assim, se defendendo com tenacidade e com energia dos ataques da sua amante, e chegou a se reconciliar interiormente com o pai.

O homicídio da jovem foi o meio de vingar seu pai ultrajado. Castigou-a pela infidelidade cometida, como se quisesse dar esta satisfação ao seu pai. Também tinha se castigado a si mesmo com essa morte, que lhe privava do objeto amado. Desta forma, os remorsos perante o pai se reduziram em tão grande medida, que não eram suficientes para vencer o impulso natural de seguir vivendo.

O estado depressivo que lhe produziu a proposição da sua amante foi suprimido desde o momento em que pôde matar sua cúmplice, 
que, por sua parte, consentia em morrer e, sobre tudo, porque matando a mulher a identificação com o pai tem sucesso na trágica cena. A mulher ficava, por um lado, morta para o pai, e pelo outro, ficava suprimido seu objeto de amor, em uma espécie de auto castigo. Se igualando com o pai nesta missão desagradável e sangrenta logra apaziguar seus sentimentos de culpa e ficar em paz com seu progenitor.

Os sentimentos mais fortes de Carlos eram o remorso perante o pai e sua fixação homossexual inconsciente a respeito do mesmo. Estes sentimentos eram mais fortes que qualquer outra tendência heterossexual. Isso é demonstrado de forma bem clara pelo resultado final da ação, cuja vítima é a amante. O elemento passivo e homossexual da tendência a separar o pai da mãe é decisivo no fato pelo qual a mãe -a amante-, cuja existência dá lugar ao conflito, é suprimida, de forma que no futuro Carlos poderá viver tranquilamente com seu pai. Que o homossexualidade é a causa da agressão contra a mulher é demonstrado pela crítica e desprezo que faz da sua cunhada e sua conduta em geral com as mulheres, com as que nunca podia estar em uma verdadeira relação sentimental. Além disso, é demonstrado pelo próprio fato realizado e, finalmente, por sua reconciliação imediata com o pai. Consegue renunciar a seu desejo incestuoso de morrer unido com sua amante, se refugiando no seu comportamento passivo homossexual a respeito do pai. Devemos advertir que esta conduta significa a satisfação invertida do complexo de Édipo, ou seja, a união homossexual com o pai. Por isso, o impulso que triunfa é o da própria conservação.

Trata-se, por tanto, de uma ação cometida, não por motivos criminais, mas principalmente por efeito de sentimentos de culpa exagerados, pelo que as causas são éticas. Carlos é um criminoso neurótico que não pode perceber seu Eu consciente no fato. Impor-lhe uma pena para fazê-lo sofrer não teria eficácia nem utilidade neste caso, que cai plenamente no domínio da psicanálise, pela qual seria possível curá-lo de devolvê-lo à sociedade, desemaranhando seu complexo de Édipo não superado. 
Revista Multidisciplinar do Nordeste Mineiro, v.1, 2021/01

ISSN 2178-6925

Como curiosidade, mencionaremos a solução jurídica do caso, segundo o vigente código penal alemão. $\mathrm{O}$ homicídio executado à petição da vítima se castiga com uma pena de privação de liberdade não inferior a três anos. A tentativa fica impune. Porém, se acontece, como neste caso, que o homicídio fracasse e se produzem lesões graves, segundo a jurisprudência do Tribunal do Império, deve ser aplicado o parágrafo 225 - presídio de dois a dez anos. O quadro penal se agrava consideravelmente. 